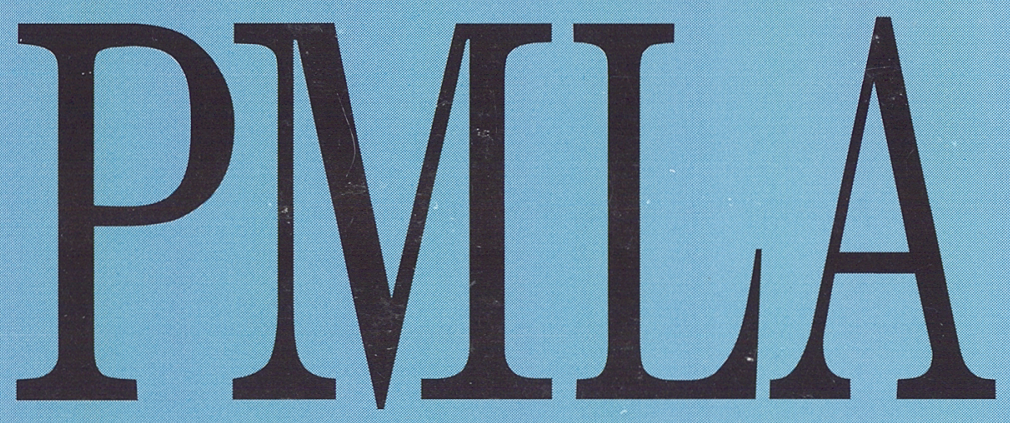

\title{
Publications of the
}
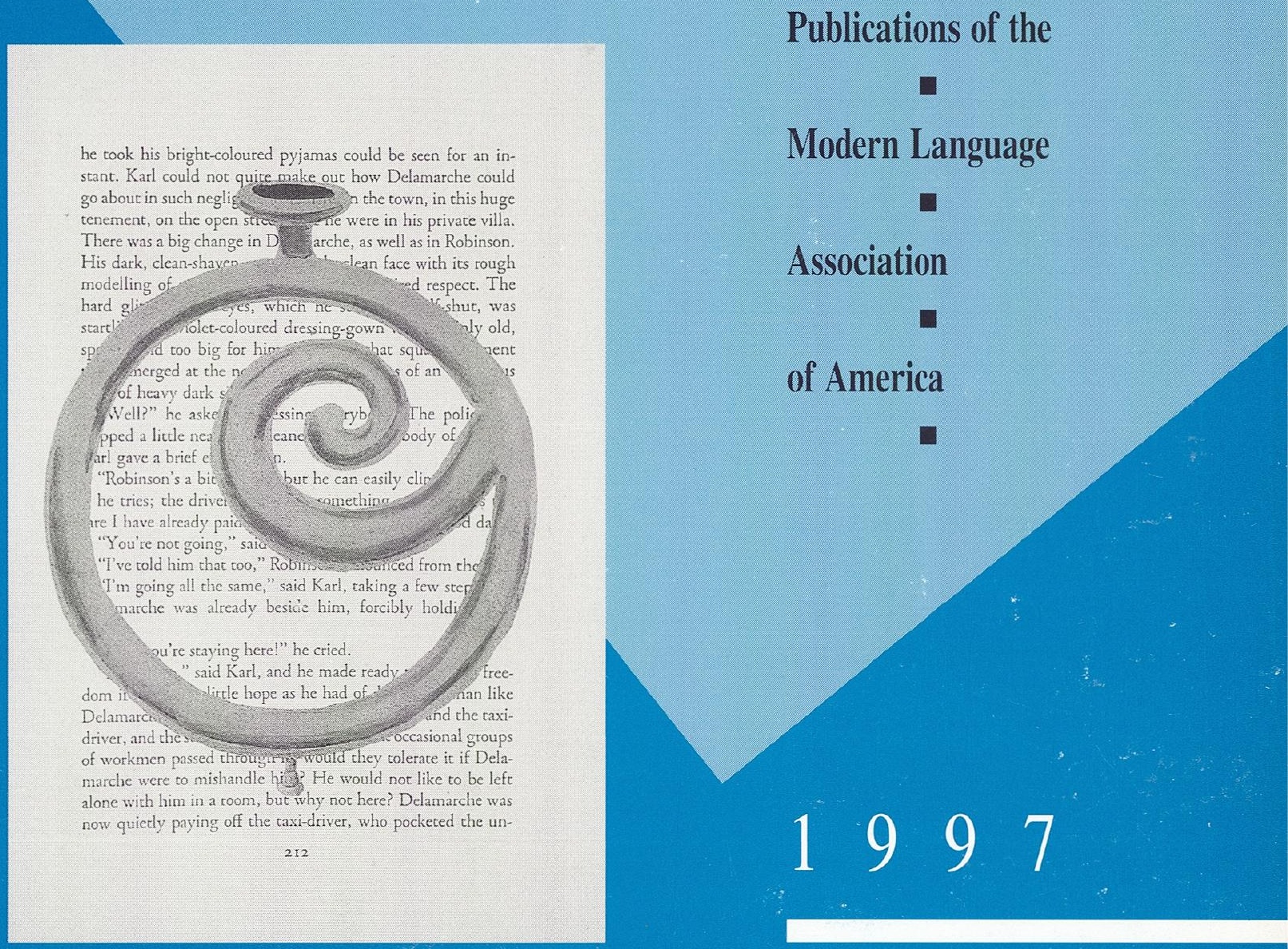

\section{MAY}




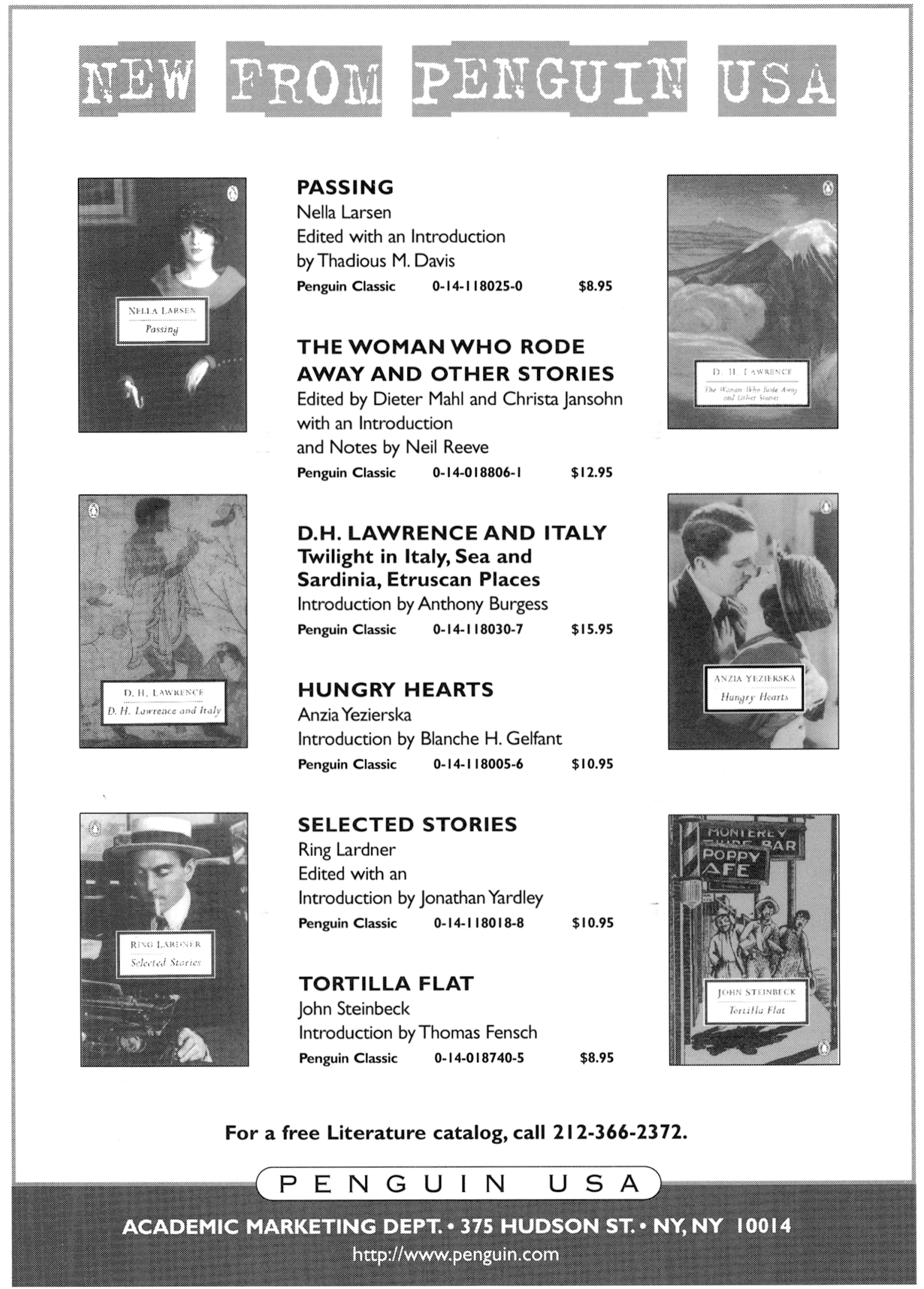




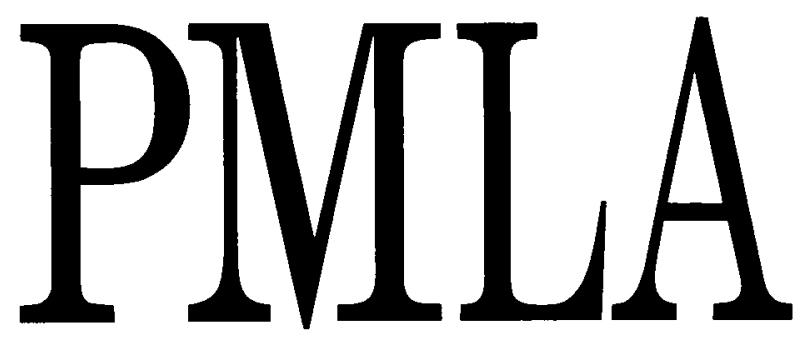

Publications of the

Modern Language Association of America

Volume 112, Number 3

Published six times a year by the association 


\section{The Modern Language Association of America}

Officers for the Year 1997

\section{Executive Council}

For the ferm ending 31 December 1997

For the term ending 31 December 1998

For the term ending 31 December 1999

For the term ending 31 December 2000

Trustees of Invested Funds

\author{
President: HERBERT LINDENBERGER, Stanford University \\ First Vice President: ELAINE SHOWALTER, Princeton University \\ Second Vice President: EDWARD W. SAID, Columbia University \\ Executive Director: PHYLLIS FRANKLIN
}

PETER BROOKS, Yale University

ANDREA A. LUNSFORD, Ohio State University, Columbus

SYLVIA MOLLOY, New York University

SUSAN NOAKES, University of Minnesota, Twin Cities

FRANCES SMITH FOSTER, Emory University

PETER UWE HOHENDAHL, Cornell University

FRANK TROMMLER, University of Pennsylvania

HEATHER DUBROW, University of Wisconsin, Madison

CATHERINE PORTER, State University College of New York, Cortland

EVE KOSOFSKY SEDGWICK, Duke University

ERIC J. SUNDQUIST, Universiry of California, Los Angeles

MARGARET W. FERGUSON, Columbia University

ROBERT SCHOLES, Brown University

GEORGE YUDICE, New York University

CAROLYN G. HEILBRUN, New York, New York

HUGH O'NEILL, New York, New York

MALCOLM B. SMITH (Managing Trustee), New York, New York

PMLA (ISSN 0030-8129) is published six times a year, in January, March, May, September, October, and November, by the Modern Language Association of America. Membership in the association is open to persons who are professionally interested in the modern languages and literatures. Annual dues, which include subscription to PMLA, are based on members' incomes and are graduated as follows: student members (seven years maximum), $\$ 20$; new regular members (first year), $\$ 35$; regular members (income under $\$ 15,000$ ), $\$ 25$; regular members (income $\$ 15,000-\$ 20,000$ ), $\$ 40$; regular members (income $\$ 20,000-\$ 30,000$ ), $\$ 50$; regular members (income $\$ 30,000-\$ 40,000$ ), $\$ 65$; regular members (income $\$ 40,000$ $\$ 50,000), \$ 75$; regular members (income $\$ 50,000-\$ 60,000$ ), $\$ 85$; regular members (income $\$ 60,000-\$ 70,000$ ), $\$ 95$; regular members (income $\$ 70,000-\$ 80,000$ ), $\$ 105$; regular members (income over $\$ 80,000$ ), $\$ 125$; joint members (two individuals sharing the same household, who receive one subscription to PMLA but two copies of all other publications), add $\$ 20$ to dues category of higher-income member; foreign members, same as regular members (use the American-dollar equivalent to ascertain the dues category). Membership applications are available on request.

The subscription price of PMLA for libraries and other institutions is $\$ 108$. A subscription including a bound volume at the end of the year is $\$ 243$, domestic and foreign. Agents deduct $4 \%$ as their fee. Single copies of the January, March, May, and October issues may be obtained for $\$ 12$ each; the September (Directory) issue for $\$ 50$; the November (Program) issue for $\$ 35$.

Issues for the current year are available from the Member and Customer Services Office of the association (212 614-6381; membership@mla.org). Claims for undelivered issues will be honored if they are received within six months of the publication date; thereafter the single-issue price will be charged.

For information about the availability of back issues, inquire of Periodical Service Company, Germantown, NY 12526 (914 941-4404). Early and current volumes may be obtained on microfilm from University Microfilms, Ann Arbor, MI 48106. Purchase of current volumes on film is restricted to subscribers of the joumal.

The office of publication and editorial offices are located at 10 Astor Place, New York, NY 10003-6981 (212 475-9500; pmlasubmissions@mla.org).

All communications concerning membership, including change-of-address notifications, should be sent to the Member and Customer Services OfficeMLA, 10 Astor Place, New York, NY 10003-6981 (212 614-6381; membership @mla.org). If a change of address also involves a change of institutional affiliation or a new e-mail address, that office should be informed of this fact at the same time.

Periodicals postage paid at New York, NY, and at additional mailing offices.

(1) 1997 by The Modern Language Association of America. All rights reserved. Printed in the United States of America.

Library of Congress Catalog Card Number 12-32040. United States Postal Service Number 449-660.

POSTMASTER: Send address changes to PMLA, Member and Customer Services Office, Modern Language Association of America, 10 Astor Place, New York, NY 10003-6981. 


\title{
Publications of the Modern Language Association
}

\author{
Published six times a year Indexes: Vols. 1-50, 1935; 51-60, 1945; 51-79, 1964
}

Editorial Board

Advisory Committee
Editor: DOMNA C. STANTON, University of Michigan, Ann Arbor Managing Editor: JUDY GOULDING Assistant Editors: ERIN TROSTLE and ERIC WIRTH Editorial Assistants: JOHN D. GOLBACH and JAMES PONIEWOZIK Advertising Manager and Administrative Assistant: KATHERINE J. FLOREY Submissions Associate: XENI FRAGAKIS

RUSSELL A. BERMAN, 1997, Stanford University GILES B. GUNN, 1999, University of California, Santa Barbara MICHAEL HOLQUIST, 1997, Yale University ROBERTA LEE JOHNSON, 1999, University of Kansas CORA KAPLAN, 1997, University of Southampton CAROL THOMAS NEELY, 1999, University of Ilinois, Urbana

LESLIE A. ADELSON, 1998, Cornell University KWAME ANTHONY APPIAH, 1997, Harvard University DANIEL BALDERSTON, 1999, Tulane University TEODOLINDA BAROLINI, 1998, Columbia University CHARLES BERNHEIMER, 1997, University of Pennsylvania CAROL L. BERNSTEIN, 1999, Bryn Mawr College MARC E. BLANCHARD, 1999, University of California, Davis JOSEPH A. BOONE, 1997, University of Southern California LAURA S. BROWN, 1998, Cornell University ROBERT L. CASERIO, 1998, Temple University ELIN DIAMOND, 1997, Rutgers University, New Brunswick JOANNE F. DIEHL, 1997, University of California, Davis LISA EDE, 1999, Oregon State University STEVEN FINK, 1998, Ohio State University, Columbus RAE BETH GORDON, 1999, University of Connecticut, Storrs SUSAN GUBAR, 1997, Indiana University, Bloomington ALICE C. HARRIS, 1998, Vanderbilt University N. KATHERINE HAYLES, 1998, University of California, Los Angeles JEAN E. HOWARD, 1997, Columbia University KATHRYN HUME, 1997, Penn State University, University Park GEORGE B. HUTCHINSON, 1999, University of Tennessee, Knoxville ULLRICH G. LANGER, 1999, University of Wisconsin, Madison H. MARSHALL LEICESTER, JR., 1997, University of Califormia, Santa Cruz ANGEL G. LOUREIRO, 1999, University of Massachusetts, Amherst JUDITH MAYNE, 1998, Ohio State University, Columbus MICHAEL McKEON, 1997, Rutgers University, New Brunswick ANNE MELLOR, 1997, University of California, Los Angeles TIMOTHY C. MURRAY, 1999, Cornell University ANNE LAKE PRESCOTT, 1999, Barnard College JEAN-JACQUES THOMAS, 1999, Duke University WILLIAM MILLS TODD III, 1998, Harvard University KATHLEEN E. WELCH, 1999, University of Oklahoma JACK ZIPES, 1998, University of Minnesota, Twin Cities 


\section{A Statement of Editorial Policy}

PMLA welcomes essays of interest to those concerned with the study of language and literature. As the publication of a large and heterogeneous association, the journal is receptive to a variety of topics, whether general or specific, and to all scholarly methods and theoretical perspectives. The ideal PMLA essay exemplifies the best of its kind, whatever the kind; addresses a significant problem; draws out clearly the implications of its findings; and engages the attention of its audience through a concise, readable presentation. Manuscripts in languages other than English are accepted for review but must be accompanied by a detailed summary in English (generally of 1,000-1,500 words) and must be translated into English if they are recommended to the Editorial Board. Articles of fewer than 2,500 words or more than 9,000 words are not considered for publication. The word count includes notes but excludes works-cited lists and translations, which should accompany foreign language quotations. The MLA urges its contributors to be sensitive to the social implications of language and to seek wording free of discriminatory overtones.

Only members of the association may submit articles to PMLA. Each article submitted is sent to at least one consultant reader and one member of the Advisory Committee. Articles recommended by these readers are then sent to the members of the Editorial Board, who meet periodically with the editor to make final decisions. Until a final decision is reached, the author's name is not made known to consultant readers, to members of the Advisory Committee and the Editorial Board, or to the editor. Because the submission of an article simultaneously to more than one refereed journal can result in duplication of the demanding task of reviewing the manuscript, it is $P M L A$ 's policy not to review articles that are under consideration by other journals. An article found to have been submitted elsewhere will not be published in $P M L A$ even if it has already been accepted for publication by the Editorial Board.

Submissions, prepared according to The MLA Style Manual, should be sent in duplicate and addressed to the Managing Editor, PMLA, Modern Language Association, 10 Astor Place, New York, NY 10003-6981. With each submission please include a self-addressed envelope and enough postage for both copies to be returned. Authors' names should not appear on manuscripts; instead, a cover sheet, with the author's name and address and the title of the article, should accompany each manuscript. Authors should not refer to themselves in the first person in the submitted text or notes if such references would identify them; any necessary references to the author's previous work, for example, should be in the third person.

\section{Criticism in Translation}

MLA members are invited to submit to the PMLA Editorial Board proposals for translations. Articles, as well as chapters or sections of books that can function as independent units, will be considered. The originals may be in any language. Two types of proposals are welcome: (1) significant scholarship from earlier periods that has not lost its forcefulness and whose retrieval in English in PMLA would be a noteworthy event for a broad body of readers or (2) contemporary work of sufficient weight and potential influence to merit the attention of the field as a whole.

A member who wishes to make a proposal should first ascertain that no previous English translation exists. The proposer should then provide the managing editor with the following materials: (1) a photocopy of the original essay, (2) an extended summary of the entire essay in English, (3) an introductory statement of approximately 1,000 words, prepared in accordance with MLA style, that will be published with the essay if the essay is accepted, (4) information on the copyright status of the original (if the translation is accepted for publication, the proposer will be responsible for obtaining permission to print it). In addition, if the proposer wishes to serve as translator of the essay or to designate a translator (who must also be an MLA member), a 1,000-word sample of the translation should be submitted; otherwise the Editorial Board will select a translator.

The translated essays should normally not exceed PMLA's 9,000-word limit. The Editorial Board will approve or decline the proposals, evaluate the quality of the translations, and cooperate with the proposers and translators. 


\section{Contents}

Cover illustration: Tim Rollins and K. O. S., Study for Amerika-A Refuge, 1991, pencil and watercolor on paper, $16^{\prime \prime} \times 13^{\prime \prime}(40.6 \times$ $33.0 \mathrm{~cm}$ ). Courtesy of Mary Boone Gallery, New York.
Special Topic . . . . . . . . . . . . . 358

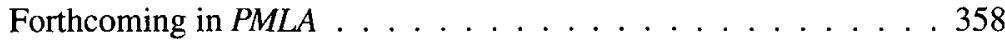

Guest Column. The Privilege of the Nonnative Speaker Claire Kramsch . . . . . . . . . . . . . . . . 359

Presidential Address 1996. Shadows of Futurity: The Literary Imagination, the MLA, and the Twenty-First Century Sandra M. Gilbert . . . . . . . . . . . . . . . . 370

The Decomposing Form of Joyce's Ulysses Henry Staten . . . . . . . . . . . . . . . . . 380

"Kissing a Negress in the Dark": Englishness as a Masquerade in Woolf's Orlando Jaime Hovey . . . . . . . . . . . . . . . . . . . . . . . . . . 393

The Wound of History: Walcott's Omeros and the Postcolonial Poetics of Affliction Jahan Ramazani

Figurations of Rape and the Supernatural in Beloved Pamela E. Barnett . . . . . . . . . . . . . . . . . . . . . 418

\section{Forum}

Contributions by Lorene M. Birden, Kenneth A. Bruffee, Douglas Bruster, Crystal Downing, Donald W. Foster, Peter C. Herman, A. Kent Hieatt, Charles W. Hieatt, James Hirsh, George Levine, David Linton, Carrie Noland, Samuel Schuman, David R. Shumway, Sidney Thomas, and Kevin Walzer . . . . . . . . . . . . . . . . 428

Report of the Executive Director . . . . . . . . . . 443

Forthcoming Meetings and Conferences of General Interest . . . 457

Index of Advertisers . . . . . . . . . . . . . . 459

Professional Notes and Comment . . . . . . . . . . . . . . . 480 Announcements 480

Journal Notes 486 Internet News 490 Minutes of the MLA Delegate Assembly 492 Meeting of the MLA Executive Council 510 In Memoriam 516

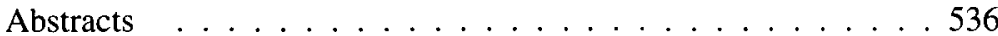

